\title{
Expression, Purification and Characterization of Ricin vectors used for exogenous antigen delivery into the MHC Class I presentation pathway
}

\author{
Daniel C. Smith ${ }^{1 *}$, Catherine J. Marsden ${ }^{1}$, J. Michael Lord ${ }^{1}$ and Lynne M. Roberts ${ }^{1}$ \\ ${ }^{1}$ Department of Biological Sciences, University of Warwick, Coventry. UK CV4 7AL \\ *To whom correspondence should be addressed. E-mail: dsmith@bio.warwick.ac.uk
}

Submitted: October 7, 2002; Revised: December 3, 2002; Accepted: December 12, 2002; Published: February 17, 2003

Indexing terms:

Abbreviations: APC, antigen presenting cells; ER, endoplasmic reticulum; MHC, major histocompatibility complex; PMSF, phenylmethylsulfonylfluoride; RTA, ricin toxin A chain; RTB, ricin toxin B chain; TAP, transport associated with antigen presentation.

\begin{abstract}
Disarmed versions of the cytotoxin ricin can deliver fused peptides into target cells leading to MHC class I-restricted antigen presentation [Smith et al. J Immunol 2002; 169:99107]. The ricin delivery vector must contain an attenuated catalytic domain to prevent target cell death, and the fused peptide epitope must remain intact for delivery and functional loading to MHC class I molecules. Expression in $E$. coli and purification by cation exchange chromatography of the fusion protein is described. Before used for delivery, the activity of the vector must be characterized in vitro, via an $N$-glycosidase assay, and in vivo, by a cytotoxicity assay. The presence of an intact epitope must be confirmed using mass spectrometry by comparing the actual mass with the predicted mass.
\end{abstract}

\section{INTRODUCTION}

Ricin, along with several protein toxins have been exploited for their intracellular trafficking and/or membrane translocation properties allowing delivery of exogenous peptides directly into the MHC class I processing and presentation pathway of target cells (1-4). Thus, ricin can be classified as a non-live vector, capable of delivering fused peptides to target cells thereby inducing a $\mathrm{CD}^{+} \mathrm{T}$ cell response. Due to the nature of these non-live vectors, ex vivo application of professional antigen presenting cells (APC) with disarmed (inactivated) toxin vectors carrying fused antigens remains a long-term goal in vaccine development. In this way, it is envisioned that re-administration of primed APC could promote a protective $\mathrm{CD}^{+} \mathrm{T}$ cell response. However, in contrast with other protein vectors described so far (4), we have shown that ricin can deliver peptides into cells in a TAP-independent manner, directly to newly synthesized MHC class I molecules in the ER of target cells (1). Indeed this strong TAP-negative bias of the ricin vector may pave the way for developing therapeutic vectors directed solely against certain TAP-negative tumours in vivo.

Ricin is a heterodimeric protein composed of two subunits, ricin A chain (RTA) and ricin B chain (RTB), that are normally disulfide bonded together. RTA has an rRNAspecific $N$-glycosidase activity and is therefore capable of inactivating cytosolic ribosomes, whilst RTB is a galactosespecific lectin able to bind the holotoxin to the target cell facilitating endocytic uptake. Productive intoxication of a cell by ricin involves receptor-mediated uptake at the cell surface, retrograde routing via the Golgi complex to the endoplasmic reticulum (ER) lumen (5-8), followed by retrotranslocation of the catalytic subunit through Sec61 channels into the cytosol (9). Upon reaching the cytosol RTA evades proteasomal degradation (10) and is thought to undergo ribosome-mediated refolding to an active moiety capable of inactivating the very molecules that helped refold the protein (11).

Although the retrograde transport of ricin can directly intersect with the MHC class I processing and presentation machinery in the cytosol and ER, respectively, allowing exogenous peptide delivery (1), there are some practical issues that have to be addressed when developing therapeutic ricin vectors. Mainly the toxicity of the vector and the stability of epitope within the fusion have to be considered. The delivery vector must therefore contain both an attenuated catalytic domain to prevent target cell death, and the fused peptide epitope must remain intact for functional processing and loading to MHC class I molecules.

C 2003. Biological Procedures Online. Published in Biological Procedures Online under license from the author(s). Copying, printing, redistribution and storage permitted. 
Here we describe the details of those methods from our published work as related to the expression, purification and characterization of potential ricin vectors for their use in antigen delivery (1).

\section{MATERIALS AND METHODS}

\section{Cell lines}

MC57 cells, a C57BL/6-derived fibrosarcoma, were grown in RPMI 1640 (Life Technologies, Rockville, MD) containing 5\% (v/v) FCS, $2 \mathrm{mM}$ L-glutamine, $100 \mathrm{U} / \mathrm{ml}$ penicillin, and $100 \mu \mathrm{g} / \mathrm{ml}$ streptomycin.

\section{Expression of recombinant RTA-peptide fusions}

The pUTA vector (12) containing the RTA-peptide fusion sequence (1) was transformed into competent $E$. coli JM101. A single transformant was used to inoculate $100 \mathrm{ml}$ of $2 \mathrm{YT}$ medium (17 g/l bactotryptone, $10 \mathrm{~g} / \mathrm{l}$ yeast extract, $5 \mathrm{~g} / \mathrm{l}$ sodium chloride) containing $100 \mu \mathrm{g} / \mathrm{ml}$ ampicillin and this was grown overnight at $37^{\circ} \mathrm{C}$. This overnight culture was used to inoculate $2 \mathrm{x} 500 \mathrm{ml}$ of $2 \mathrm{YT}$ which was then grown for 2 hours at $30^{\circ} \mathrm{C}$ in an orbital shaker. Expression was induced by the addition of IPTG to a final concentration of $0.1 \mathrm{mM}$ and incubation was continued for a further 4 hours at $30^{\circ} \mathrm{C}$. Cells were harvested by centrifugation in a JA10 rotor in a Beckman $\mathrm{J} 2-21 \mathrm{M} / \mathrm{E}$ centrifuge at $2740 \mathrm{xg}(5000$ $\mathrm{rpm})$ at $4^{\circ} \mathrm{C}$ for 15 minutes. Cell pellets were resuspended in $15 \mathrm{ml}$ of ice-cold $5 \mathrm{mM}$ sodium phosphate buffer ( $\mathrm{pH} \mathrm{6.5)}$

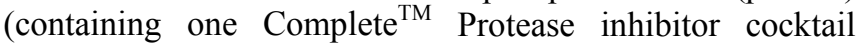
tablet, Roche). Cells were lysed using a MSE Soniprep150 sonicator at an amplitude of $15 \mu$ for 30 seconds six times with 30 second intervals keeping the cells chilled in an ice water bath at all times. Cell debris was pelleted by centrifugation in a JA20 rotor in a Beckman J2-21M/E centrifuge at $31400 \mathrm{xg}(20000 \mathrm{rpm})$ at $4^{\circ} \mathrm{C}$ for 30 minutes. The supernatant was transferred to a fresh tube and the volume made up to $50 \mathrm{ml}$ with $5 \mathrm{mM}$ sodium phosphate buffer ( $\mathrm{pH}$ 6.5).

\section{Purification of RTA-peptide fusions}

RTA-peptide fusions were purified from crude E.coli lysate by ion-exchange chromatography at $4^{\circ} \mathrm{C}$. The freshly prepared soluble cell lysate containing the over-expressed RTA-peptide fusion was immediately loaded onto a $50 \mathrm{ml}$ CM-Sepharose CL-6B column (pre-equilibrated with $5 \mathrm{mM}$ sodium phosphate $\mathrm{pH} 6.5$ ) and unbound proteins were removed by washing with 1 litre of $5 \mathrm{mM}$ sodium phosphate pH6.5. The column was washed with $100 \mathrm{ml}$ of $100 \mathrm{mM}$ $\mathrm{NaCl}$ in $5 \mathrm{mM}$ sodium phosphate $\mathrm{pH} 6.5$ and bound proteins were eluted, collecting $10 \mathrm{ml}$ fractions, in a linear gradient of $100-300 \mathrm{mM} \mathrm{NaCl}$ in the same buffer, all column steps were performed at $4^{\circ} \mathrm{C}$ with the aid of gravity. Before re-use, the column was stripped with a $500 \mathrm{ml}$ wash of $2 \mathrm{M} \mathrm{NaCl}$ in 5 $\mathrm{mM}$ sodium phosphate $\mathrm{pH} 6.5$ and re-equilibrated with 1 litre of $5 \mathrm{mM}$ sodium phosphate pH6.5. Fractions were assessed for protein content by measurement of $A_{280}$ in a Shimadzu UV-160A spectrophotometer and aliquots of suitable fractions were analyzed for RTA content by $15 \%$ SDSPAGE and Western blotting.

\section{Reassociation and quantification of RTA- peptide fusions}

\section{(a) Reassociation of RTA with RTB}

Typically, $100 \mu \mathrm{g}$ of the purified RTA-peptide fusion was mixed with $100 \mu \mathrm{g}$ of RTB (Vector Laboratories) and made up to a final volume of $2 \mathrm{ml}$ with PBS containing $100 \mathrm{mM}$ lactose and $2 \% \beta$-mercaptoethanol. This was dialysed for 16 hours against 1 litre of PBS containing $100 \mathrm{mM}$ lactose and then a further 36 hours against 5 litres of PBS.

\section{(b) Purification of peptide containing holotoxins}

Reassociated holotoxin was separated away from any free RTA on a $0.5 \mathrm{ml}$ immobilized $\alpha$-lactose column (Sigma), which had been pre-equilibrated with PBS. The dialysate was cycle loaded onto the column three times and the column was then washed with $10 \mathrm{ml}$ of PBS before eluting bound holotoxin (and free RTB) in $5 \mathrm{ml}$ of PBS containing $75 \mathrm{mM}$ galactose. Eluted protein was dialysed for 16 hours against 1 litre of PBS to remove the galactose before quantifying protein as described below.

\section{(c) Quantification of ricin holotoxins}

Known quantities of RTA (in duplicate) were separated by reducing SDS-polyacrylamide gel electrophoresis, along with duplicate samples of $20 \mu \mathrm{l}$ of the freshly reassociated holotoxins. Protein was visualized using a standard silver stain protocol and standard curve was derived from the Achain standards using Molecular Dynamics ImageQuant version 3.3. From this the quantity of RTA in the holotoxins could be derived and hence the concentration of the reassociated holotoxin.

\section{Assay of the N-glycosidase activity of RTA- peptide fusions}

\section{(a) Incubation of ribosomes with RTA-peptide fusions}

Typically for each reaction, $20 \mu \mathrm{g}$ of yeast ribosomes (see below) were incubated at $30^{\circ} \mathrm{C}$ for 1 hour with the RTApeptide fusion in 1x Endo buffer (25 mM Tris.Cl ( $\mathrm{pH} 7.6)$, 
$25 \mathrm{mM} \mathrm{KCl}, 5 \mathrm{mM} \mathrm{MgCl}_{2}$ ) in a total volume of $20 \mu \mathrm{l}$. Reactions were stopped by the addition of $100 \mathrm{ml} 2 \mathrm{x}$ Kirby buffer (section $\mathrm{f}$, see below) and $80 \mathrm{ml} \mathrm{H}_{2} \mathrm{O}$.

\section{(b) Extraction of $r R N A$}

The rRNA was obtained by two phenol-chloroform extractions and rRNA was precipitated by the addition of 0.1 volumes $2 \mathrm{M} \mathrm{NaOAc} \mathrm{pH} 6.0$ and 2.5 volumes $100 \%$ ethanol. The reaction mixtures were frozen on dry ice and the precipitated rRNA was pelleted by centrifugation at 13000 rpm for 30 minutes at $4^{\circ} \mathrm{C}$ in a Heraeus refrigerated microfuge. The pellets were washed once with $70 \%$ ethanol and dried for 15 minutes in a vacuum dessicator.

\section{(c) Aniline treatment of $r R N A$}

The rRNA pellets were resuspended in $10 \mu \mathrm{H}_{2} \mathrm{O}$ and an aliquot was quantified by measuring the $\mathrm{A}_{260}$ (an $\mathrm{A}_{260}$ of 25 is equal to $1 \mathrm{mg} / \mathrm{ml} \mathrm{rRNA}$ ). $4 \mu \mathrm{g}$ of rRNA was treated for 2 minutes at $60^{\circ} \mathrm{C}$ with $20 \mu \mathrm{l}$ of acetic-aniline (or $20 \mu \mathrm{l}$ of $\mathrm{H}_{2} \mathrm{O}$ for non-aniline treated controls). The reactions were stopped by the addition of 0.1 volumes of $\mathrm{NH}_{4} \mathrm{OAc}$ and 2.5 volumes $100 \%$ ethanol and frozen on dry ice before centrifugation for 30 minutes at $4^{\circ} \mathrm{C}$. The pellets were washed once with $70 \%$ ethanol and dried in a vacuum dessicator. The pellets were resuspended in $15 \mu \mathrm{l}$ of $60 \%$ de-ionized formamide / $0.1 \mathrm{x}$

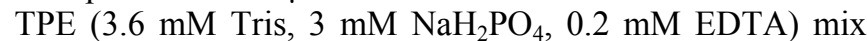
and run on a denaturing formamide gel as described below.

\section{(d) Separation of rRNA by agarose-formamide gel electrophoresis}

Prepared rRNA samples were heated at $65^{\circ} \mathrm{C}$ for 5 minutes and then cooled on ice for 5 minutes. $3 \mathrm{ml}$ of sample buffer (50\% glycerol) was added to each sample and they were loaded into wells of a horizontal $1.2 \%$ agarose, $0.1 \mathrm{x}$ TPE, $50 \%$ de-ionized formamide gel which had been preflooded with $60 \%$ formamide / $0.1 x$ TPE mix. Dye is omitted from the sample buffer so that any diagnostic fragment produced is not obscured for quantification. The samples were electrophoresed in $0.1 \mathrm{x}$ TPE at $25-28 \mathrm{~mA}$ for $60-90$ minutes and then stained for 15 minutes in $500 \mathrm{ml}$ of water containing $25 \mu \mathrm{l}$ of $10 \mathrm{mg} / \mathrm{ml}$ ethidium bromide before destaining in water for at least 30 minutes. The RNA was visualized on a short-wave ultra-violet transilluminator, and digital images recorded using a GDS8000 Gel Documentation and Analysis System (Ultra-Violet Products, Cambridge, UK).

\section{(e) Quantification of RNA fragments}

The percentage of depurination was quantified from digital images of ethidium bromide stained gels using Molecular Dynamics Imagequant version 3.3. The lengths of the aniline fragment (the fragment produced by ricin A-chain induced depurination, followed by acetic-aniline treatment) and the 5.8S rRNA fragment are known to be 369 bases and 160 bases respectively. The intensity of aniline band could therefore be quantified, using the intensity of 5.8S rRNA band in the same lane of the agarose-formamide gel as a loading control. A background value was also calculated by quantifying an area of the gel close to the aniline band and relating this to the $5.8 \mathrm{~S}$ rRNA in the same lane. This background value was subtracted giving a final value referred to as the "percentage depurination."

Depurination was quantified by the following equation:

$$
\begin{gathered}
\% \text { depurination }= \\
{[(\text { intensity of aniline fragment / intensity of 5.8S rRNA }) \times} \\
(160 / 369)] \\
\times 100-\text { background }
\end{gathered}
$$

In order to compare the activities of RTA-peptide fusions with wild-type RTA, a value of the concentration of protein required for $50 \%$ depurination $\left(\mathrm{D}_{50}\right)$ was calculated with $35 \%$ depurination being half of the maximal depurination. It is of interest to note that RTA never produces a $100 \%$ dupurination of yeast ribosomes, reaching only a 70\% level. This lack of complete dupurination is thought to be due to the different conformations that the ribosome adopts during protein synthesis resulting in a small proportion of ribosomes that are refractory to $N$-glycosidase activity (12).

\section{(f) Preparation of Kirby reagent}

$6 \mathrm{~g}$ of 4-amino salicylic acid (sodium salt) was dissolved in $25 \mathrm{ml}$ of $200 \mathrm{mM}$ Tris.Cl, $\mathrm{pH} 7.6 / 40 \mathrm{mM} \mathrm{KCl}$ and to this $10 \mathrm{ml}$ of $10 \%$ tri-isopropylnapthalene sulphonic acid was added. Tris-saturated phenol was added until the solution was no longer cloudy. The volume was made up to $50 \mathrm{ml}$ with sterile distilled water and the solution was stored at $20^{\circ} \mathrm{C}$.

\section{(g) Preparation of acetic-aniline reagent.}

$0.5 \mathrm{ml}$ of glacial acetic acid was mixed with $7 \mathrm{ml}$ of sterile distilled water and $1 \mathrm{ml}$ of redistilled aniline. The $\mathrm{pH}$ was adjusted to 4.5 with glacial acetic acid and the solution was made up to $11 \mathrm{ml}$ with sterile distilled water. Aniline reagent was stored at $4^{\circ} \mathrm{C}$ in the dark.

\section{Preparation of yeast ribosomes}

A single colony of yeast strain ABYS1 was grown for 24 hours at $30^{\circ} \mathrm{C}$ at $250 \mathrm{rpm}$ in YPD medium $(1 \%(\mathrm{w} / \mathrm{v})$ yeast extract, $2 \% \quad(\mathrm{w} / \mathrm{v})$ bactopeptone, $2 \% \quad(\mathrm{w} / \mathrm{v})$ glucose $)$ supplemented with $1 \mathrm{ml}$ of $0.2 \%$ adenine and $0.2 \%$ uracil per $100 \mathrm{ml}$ of media.

$500 \mathrm{ml}$ of YPD medium (supplemented with adenine and uracil) was inoculated with this $10 \mathrm{ml}$ culture and grown for 12 hours at $30^{\circ} \mathrm{C}$ at $250 \mathrm{rpm}$ in an orbital shaker. Cells were harvested by centrifugation in a JA10 rotor in a Beckman J2$21 \mathrm{M} / \mathrm{E}$ centrifuge at $2740 \mathrm{xg}(5000 \mathrm{rpm})$ at $4^{\circ} \mathrm{C}$ for 5 minutes. Cell pellets were washed 3 times by resuspending 
in $100 \mathrm{ml}$ of deionized, sterile water and centrifuging again at $2740 \mathrm{xg}(5000 \mathrm{rpm})$ at $4^{\circ} \mathrm{C}$ for 5 minutes. After these 3 washes, the cell pellet was resuspended in 3 pellet volumes of lysis buffer (100 mM KOAc, $2 \mathrm{mM} \mathrm{Mg}(\mathrm{OAc})_{2}, 20 \%$ (v/v) glycerol, $20 \mathrm{mM}$ Hepes/KOH $\mathrm{pH} 7.4)$ containing PMSF at a final concentration of $100 \mathrm{mM}$, and transferred to oakridge tubes. An equal volume of acid-washed glass beads was added and cells were lysed by vigorous vortexing at $4^{\circ} \mathrm{C}$ for 4 to 5 minutes. Beads were pelleted by centrifugation at 750 $\mathrm{xg}(1250 \mathrm{rpm})$ in a Beckman GPR centrifuge (GH3.7 rotor) for 5 minutes and the supernatant was placed into a fresh oakridge tube without disturbing the bead pellet. Cell debris was then pelleted by centrifugation in a JA20 rotor in a Beckman J2-21M/E centrifuge at $31400 \mathrm{xg}(20000 \mathrm{rpm})$ at $4^{\circ} \mathrm{C}$ for 20 minutes. The supernatant was placed into $3 \mathrm{ml}$ polycarbonate thick walled ultracentrifuge tubes and ribosomes were pelleted by centrifugation at $386000 \mathrm{xg}$ $(100000 \mathrm{rpm})$ in a Beckman TLA 100.3 rotor. The supernatants were discarded and the pellets were rinsed twice with $100 \mu \mathrm{l}$ of $1 \mathrm{x}$ Endo buffer $(25 \mathrm{mM}$ Tris. $\mathrm{Cl}(\mathrm{pH}$ 7.6), $25 \mathrm{mM} \mathrm{KCl}, 5 \mathrm{mM} \mathrm{MgCl}$ ) before resuspending in a final volume of $500 \mu \mathrm{l}$ of 1x Endo buffer.

The concentration of ribosomes was estimated by measuring the $A_{260}$ (an $A_{260}$ of 25 is equal to $2 \mathrm{mg} / \mathrm{ml}$ ribosomes), before storing in aliquots at $20 \mu \mathrm{g} / \mu \mathrm{l}$ at $-70^{\circ} \mathrm{C}$.

\section{Cytotoxicity assay}

MC57 target cells were plated out in a volume of $100 \mu \mathrm{l}$ in 96 well plates at a density of $1.5 \times 10^{5}$ cells $/ \mathrm{ml}$ and overlaid with a further $100 \mu \mathrm{l}$ of RPMI (5\% FCS/2 mM glutamine) before incubating for 16 hours (overnight) at $37^{\circ} \mathrm{C}$. The medium was removed and wells were gently washed with sterile PBS. $100 \mu \mathrm{l}$ of each toxin dilution in RPMI $(5 \%$ FCS/2 mM glutamine) was added to each well in quadruplicate. The plates were incubated for 4 hours at $37^{\circ} \mathrm{C}$ after which the toxin was removed and the wells were gently washed with sterile PBS.

Protein synthesis was measured by incubating the plates at $37^{\circ} \mathrm{C}$ in the presence of $1 \mu \mathrm{Ci}$ of $\left[{ }^{35} \mathrm{~S}\right]$ methionine in $50 \mu \mathrm{l}$ of PBS per well. After 90 minutes, the plates were washed three times with ice-cold 5\% trichloroacetic acid in order to precipitate labelled proteins. The plates were washed a further 3 times with ice-cold PBS and $200 \mu \mathrm{l}$ of scintillant (OptiPhase "Supermix") was added to each well. Each plate was sealed and shaken for 5 minutes before counting in a Wallac 1450 MicroBeta Trilux liquid scintillation counter.

Background radioactivity, from wells containing media only was deducted from each value and the level of protein synthesis was calculated as a percentage of toxin-free control cells.

\section{Molecular Mass determination of RTA-peptide fusions by Mass Spectrometry}

Purified RTA-peptide fusions were dialysed against $5 \mathrm{mM}$ ammonium bicarbonate (Sigma) pH 6.7, and concentrated to a final RTA concentration of $20 \mathrm{mM}$ in a Centricon 10
(Amicon). The molecular mass of the fusion was determined by electrospray ionization mass spectrometry (Proteomics Facility, University of Warwick).

\section{RESULTS AND DISCUSSION}

We created a genetic fusion of DNA for the H-2D ${ }^{b}$-restricted influenza nucleoprotein NP 366-374 peptide (ASNENMDAM) (13) to the 5' end of the cDNA encoding a catalytic site mutant (R180H) of RTA (14). Potential clones were fully sequenced to confirm the presence of the fused DNA. The fusion protein, termed nNP-RTA, was expressed in, and purified from E. coli JM101. The expression vector has been previously used to generate a high yield (10-20 mg) of soluble RTA protein $(10,12,14)$.

RTA expression was induced in mid-log cultures, grown in 2YT medium at $30^{\circ} \mathrm{C}$, with the addition of IPTG. Various concentrations of IPTG were tested; strong induction was obtained with $0.1 \mathrm{mM}$ IPTG, resulting in a total yield of soluble nNP-RTA of $8-15 \mathrm{mg} / \mathrm{L}$ of bacterial culture.

Following sonication of the bacterial cell pellet in $5 \mathrm{mM}$ sodium phosphate buffer ( $\mathrm{pH}$ 6.5), the nNP-RTA fusion was purified from the soluble fraction by ion exchange chromatography using a cation exchange matrix. After binding, the column was first washed in buffer containing $100 \mathrm{mM} \mathrm{NaCl}$, then a linear gradient $(100 \mathrm{mM}-300 \mathrm{mM}$ $\mathrm{NaCl}$ ) was applied to the column, and collected in $10 \mathrm{ml}$ fractions (Fig. 1). The nNP-RTA eluted in $115 \mathrm{mM}-185$ $\mathrm{mM} \mathrm{NaCl}$ (fractions 4-22; Fig. 1), to a purity of approximately $90 \%$. Western blot analysis using antibodies directed against RTA confirmed the identity of the fusion (data not shown). Further purification at this stage was not needed, as following specific reassociation of the nNP-RTA with RTB, the resulting holotoxin was then separated away from any contaminants (see below).

Interestingly however, purification repeatedly showed two species of the fusion protein, a slower migrating form (Fig. 1, nNP-RTA) and a faster migrating band (Fig. 1, RTA*). The presence of protease inhibitors in the initial sonication buffer, and during the $100 \mathrm{mM} \mathrm{NaCl}$ wash, increased the relative proportion of the higher band seen on elution (data not shown).

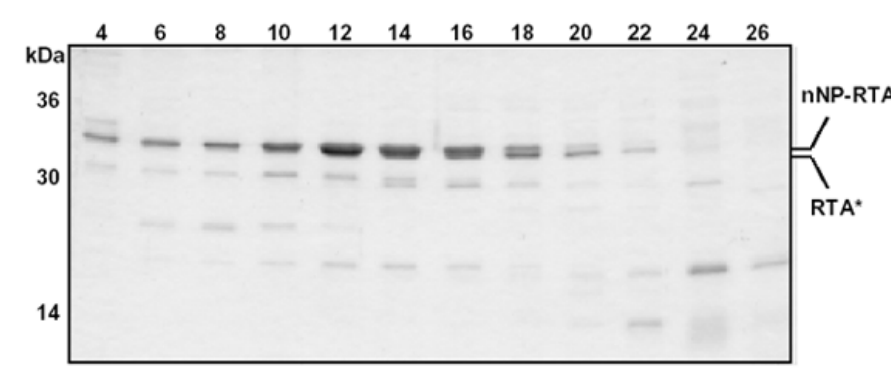

Fig. 1: Purification of nNP-RTA. Fractions obtained from the linear salt gradient used to elute the fusion protein from the cation exchange matrix were resolved by reducing SDS-PAGE (15\%), and stained with coomassie blue. The prominent band at $\sim 34 \mathrm{kDa}$ corresponds to the nNP-RTA protein (doublet). Fractions 4-18 show the higher molecular weight nNP-RTA, whilst fractions 12-22 show the nNP-cleaved RTA (RTA*). 
In order to characterize the chimera, both the early fractions (4-12), containing predominantly the higher band, and the later fractions (14-22) were separately pooled and concentrated. The proteins were dialysed into a volatile buffer ( $5 \mathrm{mM}$ ammonium bicarbonate $\mathrm{pH}$ 6.7) and their respective molecular masses were determined by mass spectrometry (electrospray ionization). The slower migrating, higher band produced a clean multiple charge series (Fig. 2, insert), which when deconvoluted gave a calculated molecular mass of $30854.8( \pm 0.3)$ daltons (Fig. 2, main). The experimental value was in agreement with the predicted theoretical mass for nNP-RTA of 30854.83 daltons (http://www.expasy.ch/tools/pi_tool.html), confirming the upper band was indeed nNP-RTA. The lower band gave an experimental mass that corresponded to the predicted mass of wild type RTA (data not shown), indicating that the NP peptide had been cleaved from the RTA fusion at some time during cell lysis and/or purification. Only the full size fusion was used for further analysis and antigen presentation studies.

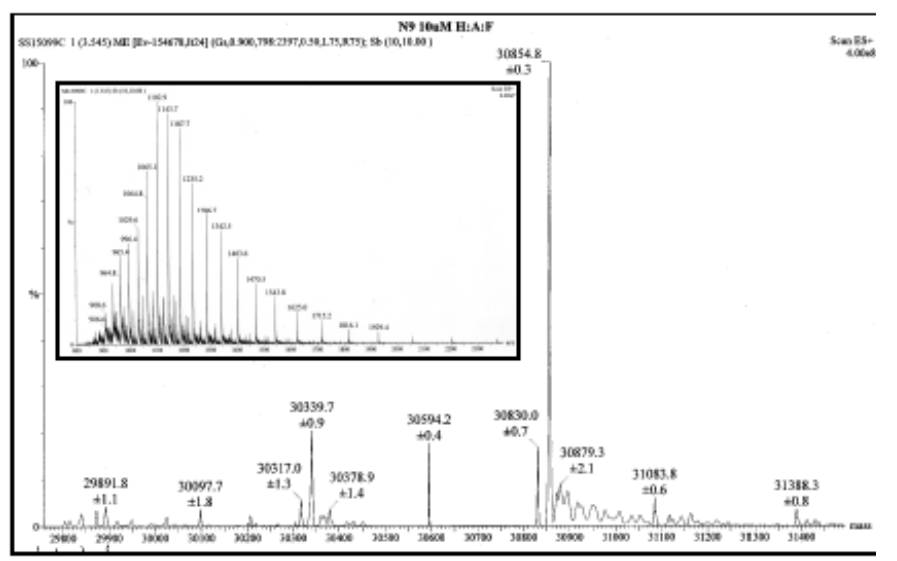

Fig. 2: The nNP-peptide is present in the fusion vector. nNP-RTA was analyzed by electrospray ionization mass spectrometry. The multiple charged series (insert) is shown. The deconveluted spectra (main) shows the molcular mass of the nNP-RTA fusion (30854.8 \pm 0.3 daltons).

However, once purified the nNP-RTA fusion remained stable (stored at $-20^{\circ} \mathrm{C}$ in $\mathrm{PBS}$ containing $15 \%$ glycerol) for up to 6 months with no further cleavage of the peptide or degradation of the complete fusion (data not shown).

The rRNA-specific $N$-glycosidase activity of the nNP-RTA fusion towards isolated yeast ribosomes was determined to be 380 fold lower than that of wild-type RTA (Fig. 3). The reduction in activity of nNP-RTA could be solely attributed to the presence of the active site substitution $\mathrm{R} 180 \mathrm{H}$, known to reduce enzymatic activity by $400-750$ fold (14), and not the presence of the NP peptide. Indeed, a wild type RTA fusion with the NP peptide exhibited the same catalytic activity as the native toxin (data not shown). Taken together, these data indicate that the NP peptide does not affect the function of the RTA portion of the fusion, implying that the structure of the fusion, as compared to wild type RTA, was not significantly altered.
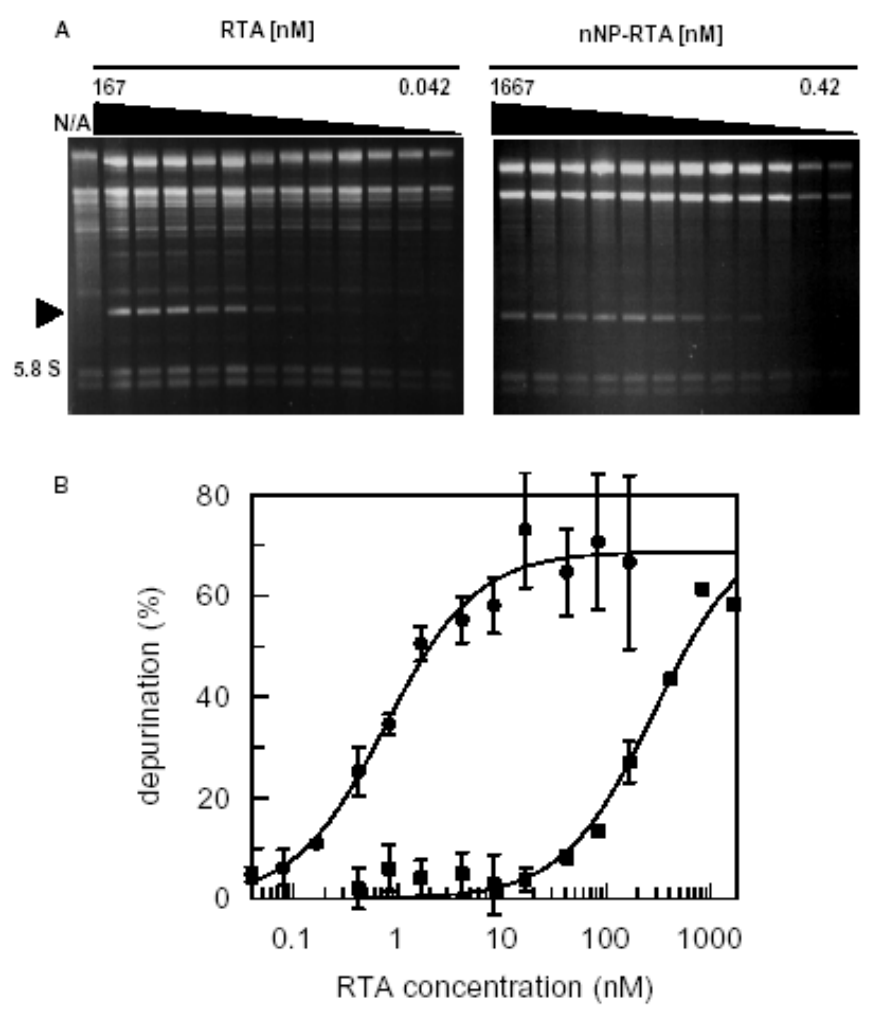

Fig. 3: N-glycosidase activity of nNP-RTA compared to wild type RTA. Isolated yeast ribosomes $(20 \mu \mathrm{g})$ were incubated with increasing nNP-RTA or wild type RTA for 60 minutes at $30^{\circ} \mathrm{C}$. rRNA was isolated and $4 \mu \mathrm{g}$ was aniline-treated and electrophoresed on an agarose/formamide gel. rRNAs were quantified from digital images using Imagequant software (A). The depurination was calculated by relating the amounts of the aniline-fragment (A; arrowhead) and the 5.8S rRNA and expressed as a percentage. A toxinincubated non-aniline treated control is shown (N/A). A graphical representation of the depurination calculated for RTA $(\bullet)$ and nNP-RTA (ם) is shown (B). Symbols indicate the experimental data; error bars represent the standard deviation of at least 2 experiments and solid lines represent best-fitted curves.

To enable intercellular delivery of the NP peptide, the fusion protein must be reassociated with the galactose-specific lectin RTB. The holotoxin can then bind to and enter cells via receptor-mediated endocytosis. Equal amounts $(100 \mu \mathrm{g})$ of nNP-RTA and plant-derived RTB were mixed in the presence of the reducing agent $\beta$-mercaptoethanol in PBS containing $100 \mathrm{mM}$ lactose, dialysed first against PBS containing $100 \mathrm{mM}$ lactose for 16 hours, then against PBS for 36 hours. Un-reassociated RTB is moderately labile, and therefore forms homodimers to aid stability, however such dimers would impair any association with nNP-RTA. The presence of reducing agent and the lactose in the buffer was shown to increase the efficiency of reassociation from $12 \%$ to $25-35 \%$. Such an increase in efficiency could have occurred by disulphide-bond reduction of any RTB dimers that may have been present and subsequent stabilization of monomeric RTB by the presence of the lactose.

Reassociated nNP-ricin was purified by affinity chromatography using immobilized $\alpha$-lactose. Only 
reassociated holotoxin and non-associated RTB will bind to the column through the lectin activity of the B chains. Extensive washing with PBS removes any free nNP-RTA, and other contaminants. The nNP-ricin, and any nonassociated B-chain, was then eluted from the column by competition with $75 \mathrm{mM}$ galactose. The presence of nonassociated RTB in the sample was shown not to affect the binding, routing or toxicity of wild type holotoxin, indeed wild-type RTA reassociated to RTB has the same cytotoxicity as plant derived ricin (data not shown). The eluted fractions were dialysed against PBS, to remove the free sugar, before being concentrated and quantified. Reducing SDS-PAGE of the nNP-ricin (known volume, 5 $\mu \mathrm{l})$ was performed, along with known amounts (ng) of native RTA and then silver-stained (Fig. 4A).

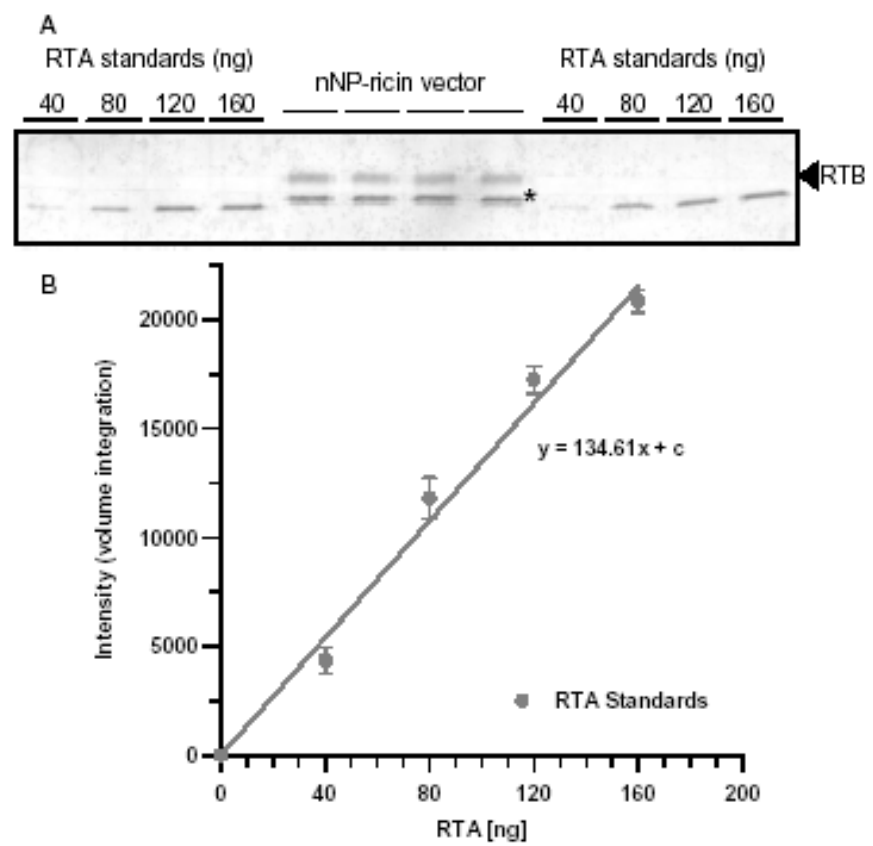

Fig. 4: Quantification of reasociated nNP-ricin. RTA standards (ng) along with $5 \mu \mathrm{l}$ of the reassociated nNP-ricin (nNP-RTA shown by asterisk) were resolved by reducing SDS-PAGE (15\%), and sliver stained (A). Band intensities were determined for the RTA standards $(\bullet)$ by scanning laser densitometry, and calibration curve plotted (B). Linear regression analysis produced the equation of the graph $(\mathrm{y}=134.61 \mathrm{x}+\mathrm{c})$. Error bars represent percentage standard deviation from the mean.

The resulting bands, corresponding to the RTA standards, were quantified by scanning laser desitometery, and a standard curve plotted (Fig. 4B). Only the bands representing the full-size nNP-RTA (Fig. 4A, *) were scanned, and the amount of each sample was determined using the equation of the graph $(\mathrm{y}=134.61 \mathrm{x}+\mathrm{c}$, where $\mathrm{c}=0$, and $\mathrm{y}$ corresponds to the scanned value). The average value for nNP-RTA was then multiplied by a factor of two (since RTA and RTB have the same naked molecular mass), and divided by the volume loaded, to convert to a holotoxin concentration. As accurate concentration measurements were essential for the use of the delivery vector in mammalian cells, this quantitation procedure was repeated no less than 3 times. The average concentration of the nNP-ricin delivery vector was 51.45 $( \pm 1.7) \mu \mathrm{g} / \mathrm{ml}(686 \mathrm{nM})$, giving a reassociation efficiency of $32.15 \%$.

Murine fibrosarcoma cells (MC57) were assayed for their sensitivity to the nNP-ricin vector in order to determine correct vector routing, and the therapeutic dose range (75 $100 \%$ cellular protein synthesis remaining) of the vector. MC57 cells were still sensitive to nNP-ricin, but to a lesser degree than wild type ricin (Fig. 5).

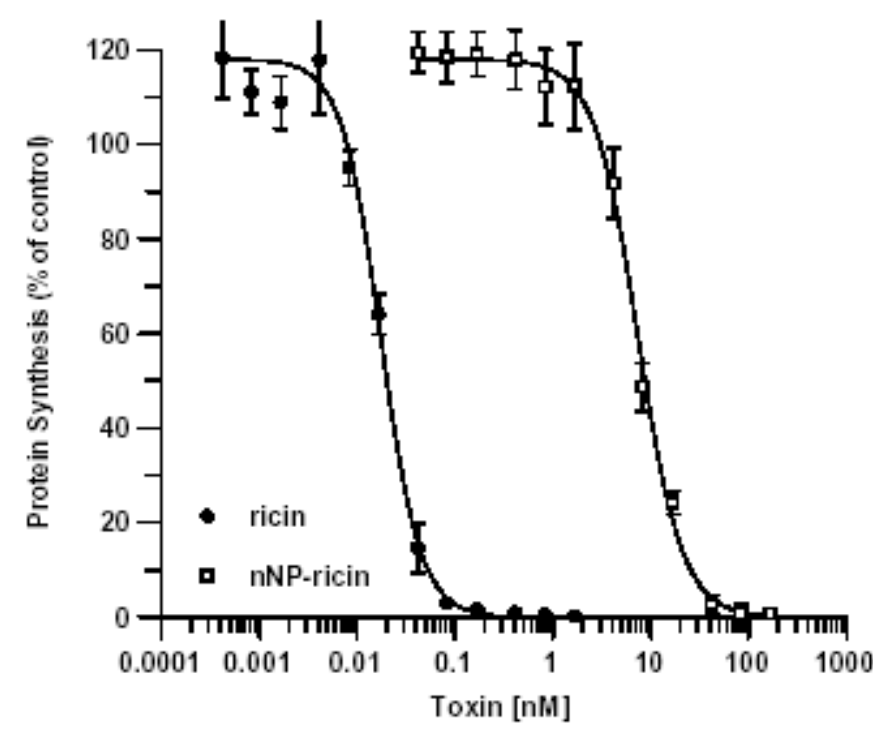

Fig. 5: Sensitivity of MC57 cells challenged with either nNP-ricin or wild type ricin. MC57 cells $\left(1.5 \times 10^{4}\right)$ were incubated with increasing concentrations of either nNP-ricin $(\square)$ or wild type ricin $(\bullet)$ for 16 hours at $37^{\circ} \mathrm{C}$. Incorporation of $\left[{ }^{35} \mathrm{~S}\right]$-methionine was used to determine remaining cellular protein synthesis, compared to untreated control cells. Error bars represent percentage standard deviation from the mean.

The $\mathrm{IC}_{50}$ values (half maximal protein synthesis inhibition) for $\mathrm{nNP}-$, and wild type ricin, were $6.95( \pm 0.44) \mathrm{nM}$ and $0.0155( \pm 0.0037) \mathrm{nM}$ respectively, corresponding to a 467 $( \pm 114)$-fold decrease in cytotoxicity of the delivery vector. Such a decrease in sensitivity was consistent with the published data for ricin carrying a $\mathrm{R} 180 \mathrm{H}$ substitution (14), again supporting the data that the NP-peptide had not altered the normal activity of the protein. MC57 cells were completely protected from nNP-ricin following treatment with brefeldin A (data not shown). Such a protection indicates a prerequisite for retrograde Golgi transit, a known requirement for ricin intoxication (15), suggesting that routing of the delivery vector is essentially the same as for the wild type toxin. For delivery purposes the nNP-ricin vector must not heavily compromise target cell protein synthesis, as such, no less than $75 \%$ protein synthesis must still occur in the MC57 target cells. Therefore, nNP-ricin concentrations up to and including $6.5 \mathrm{nM}(400 \mathrm{ng} / \mathrm{ml})$ would be tolerated for delivery. It is of interest to note that complete attenuation of activity may not be required for such delivery vectors. It has been suggested that a mild toxic 
effect resulting in a localized non-specific immune response could be beneficial for such vectors (4). Indeed, native cholera toxins from Vibrio cholerae (16), and pertussis toxin from Bordetella pertussis (17), have been shown to promote the maturation of specialized antigen presenting cells, leading to the activation of an immune response.

In conclusion, we have characterized the nNP-ricin vector for use in delivery to target cells. Characterization has confirmed that the vector contains an attenuated catalytic domain to prevent target cell death, and in doing so a therapeutic range for the vector was determined. Furthermore, we have shown that the N-terminally fused peptide epitope remains intact following purification. The ricin vector can now be used in studies focusing on intracellular delivery, investigating specific $\mathrm{CD}^{+}$ presentation via MHC class I molecules (1).

\section{ACKNOWLEDGMENTS}

The work was supported by a Wellcome Trust Program Grant (to L.M.R. and J.M.L.) and a U.K. Biotechnology and Biological Sciences Research Council project grant (to J.M.L.).

\section{REFERENCES}

1. Smith DC, Gallimore A, Jones E, Roberts B, Lord JM, Deeks D, Cerundolo V, Roberts LM. Exogenous peptides delivered by ricin require processing by signal peptidase for transporter associated with antigen processing-independent MHC Class I-restricted presentation. J Immunol. 2002;169:99-107.

2. Noakes KL, Teisserenc HT, Lord JM, Dunbar PR, Cerundolo V, Roberts LM. Exploiting retrograde transport of Shiga-like toxin 1 for the delivery of exogenous antigens into the MHC class I presentation pathway. FEBS Lett. 1998;453:95-99.

3. Haicheur N, Bismuth E, Bosset S, Adotevi O, Warnier G, Lacabanne V, Regnault A, Desaymard C, Amigorena S, Riccardi-Castagnoli P, Goud B, Fridman WH, Johannes L, Tartour E. The B-subunit of Shiga toxin fused to a tumor antigen elicits CTL and targets dendritic cells to allow MHC class I restricted presentation of peptides derived from exogenous antigens. J Immunol. 2000;165:3301-3308.

4. Smith DC, Lord JM, Roberts LM, Tartour E, Johannes L. $1^{\text {st }}$ Class Ticket to Class I: Protein Toxins as Pathfinders for Antigen Presentation. Traffic. 2002;3:695-702.

5. Sandvig K, Garred O, Prydz K, Kozlov J, Hansen SH, van Deurs B. Retrograde transport of endocytosed Shiga toxin to the endoplasmic reticulum. Nature. 1992;358:510-512.

6. Simpson JC, Dascher C, Roberts LM, Lord JM, Balch WE. Ricin cytotoxicity is sensitive to recycling between the endoplasmic reticulum and the Golgi complex. $J$ Biol Chem. 1995;270:20078-20083.

7. Rapak A, Falsnes P, Olsnes S. Retrograde transport of mutant ricin to the endoplasmic reticulum with subsequent translocation to cytosol. Proc Natl Acad Sci USA. 1997;94:3783-3788.

8. Simpson JC, Smith DC, Roberts LM, Lord JM. Expression of mutant dynamin protects cells against diphtheria toxin but not against ricin. Exp Cell Res. 1998;239:293-300.

9. Simpson JC, Roberts LM, Römisch K, Davey J, Wolf HD, Lord JM. Ricin A chain utilises the endoplasmic reticulum-associated protein degradation pathway to enter the cytosol of yeast. FEBS Lett. 1999;459:80-84.

10. Deeks ED, Cook JP, Day PJ, Smith DC, Roberts LM, Lord JM. The low lysine content of ricin A chain reduces the risk of proteolytic degradation after translocation from the endoplasmic reticulum to the cytosol. Biochemistry. 2002;41:3405-3413.

11. Argent RH, Parrott AM, Day PJ, Roberts LM, Stockley PG, Lord JM, Radford SE. Ribosome-mediated folding of partially unfolded ricin A-chain. $J$ Biol Chem. 2000;275:9263-9269.

12. Ready MP, Kim Y, Robertus JD. Site-directed mutagenesis of ricin A-chain and implications for the mechanism of action. Proteins. 1991;10:270-278.

13. Elliott T, Smith M, Driscoll P, McMicheal A. Peptide selection by class I molecules of the major histocompatibility complex. Curr Biol. 1993;3:854-859.

14. Day PJ, Ernst SR, Frankel AE, Monzingo AF, Pascal JM, Molina-Smith MC, Robertus JD. Structure and activity of an active site substitution of ricin A chain. Biochemistry. 1996;35:11098-11103.

15. Sandvig K, Prydz K, Hansen SH, van Deurs B. Ricin transport in brefeldin A-treated cells: correlation between Golgi structure and toxic effect. J Cell Biol. 1991;115:971-981.

16. Gagliardi MC, Sallusto F, Marinaro M, Langenkamp A, Lanzavecchia A, De Magistris MT. Cholera toxin induces maturation of human dendritic cells and licences them for Th2 priming. Eur J Immunol. 2000;30:23942403.

17. Ausiello CM, Fedele G, Urbani F, Lande R, Di Carlo B. Native and genetically inactivated pertussis toxins induce human dendritic cell maturation and synergize with lipopolysaccharide in promoting $\mathrm{T}$ helper type 1 responses. J Infect Disease. 2002;186:351-360. 